\title{
A Rare Case Report of an Infant With Bilateral Nephroblastoma
}

\section{KANDLA SHARMA', ANKIT MANGLA²}

Nephrogenic rest is the metanephric blastema that persists at birth. When found in multiple numbers, these rests are referred to as nephroblastomatosis. We report a rare case of a 3 month old female infant with bilateral nephroblastoma detected soon after birth and treated successfully with chemotherapy alone. Regular investigative procedures are a must to reveal these kind of rare disorders.

KEYWORDS: Metanephric blastema, Nephroblastomatosis, Wilms' tumor

\section{INTRODUCTION}

Metanephric blastema that persists at the birth is known as nephrogenic rest; these rests when present in multiple numbers are referred to as nephroblastomatosis and are present in approximately $1 \%$ of infants at autopsy. These nephrogenic rests also have the potential to undergo malignant transformation but fortunately it occurs in less than $1 \%$ of subjects. ${ }^{1}$ The natural history of nephroblastomatosis is highly variable with few lesions regressing spontaneously without any treatment while others may increase in size and turn into Wilms' tumor later during infancy or childhood. ${ }^{2}$

\section{CASE SUMMARY}

This case report documents the case of a 3 month old female infant born to a 29 year old primigravida mother at full term by LSCS with a birth weight of $3.2 \mathrm{~kg}$. She had no antenatal complications and cried immediately at birth with APGAR score 9,9. Her antenatal scans revealed echogenic focus in B/L kidneys. She had no features of dysmorphism, hypertension or any urinary symptoms. Her neonatal period was uneventful and she gained weight appropriately. On day $15^{\text {th }}$ of life, repeat ultrasound KUB was done which showed echogenic mass of $2.2 \times 1.4 \mathrm{~cm}$ in upper pole of left kidney and $0.9 \times 1.0 \mathrm{~cm}$ in upper pole of right kidney (Figure 1). Following this contrast CT scan was done on day $19^{\text {th }}$ of life which revealed well defined hypodense space occupying lesion $(2.1 \times 1.6 \mathrm{~cm})$ in upper pole of left kidney and well defined hypodense lesion ( $0.9 \mathrm{x}$ $0.9 \mathrm{~cm}$ ) in upper pole of right kidney (Figure 2). In view of the age of the patient possibility of $\mathrm{B} / \mathrm{L}$ nephroblastomatosis

was considered. Investigations done revealed $\mathrm{Hb}$ $=11.2 \mathrm{~g} / \mathrm{dl}, \mathrm{TLC}=14700 / \mathrm{cumm}$, Platelets $=5.2$ lac/cumm, BUN/Creatinine: 10.6/o.45, RFT/Electrolytes/LFT: normal. In view of suspected benign lesion and absence of any symptoms child was discharged with plan to repeat USG KUB after 6 weeks. Repeat USG scan at $9^{\text {th }}$ week of life revealed enlarging mass in both kidneys with left kidney showing hyperechoic mass of $2.3 \times 2.2 \mathrm{~cm}$ in upper pole with vascularity and right kidney showing hyperechoic mass $1.6 \mathrm{x}$ $1.3 \mathrm{~cm}$ along with vascularity. In view of enlarging mass size renal biopsy was planned from left kidney which revealed undifferentiated blastema, fibroblast like stroma and epithelial elements and mesenchymal components suggestive of $\mathrm{B} / \mathrm{L}$ nephroblastoma. Pediatric hemato-oncologist consult was taken and child underwent Left nephrectomy and was started on chemotherapeutic regimen of vincristine, actinomycin-D, and doxorubicin. On follow up after 3 months tumour size of right kidney decreased and no evidence of metastasis was seen.

\section{DISCUSSION}

The embryologic development of the kidneys starts around $5^{\text {th }}$ week of gestation and is completed by $35-36$ gestation weeks. ${ }^{3}$ The nephrogenic rests cells are abnormally persistent clusters of embryonal cells which are present at birth, representing microscopic dysplasias of the developing kidneys. These rests are found in 
approximately $1 \%$ of infant kidneys at autopsy. ${ }^{1}$ Nephroblastomatosis signifies the presence of multiple or diffuse nephrogenic rests cells. Nephroblastomatosis is also known as precursor lesions of Wilms' tumor ${ }^{4}$ which is the most common malignant tumor of abdomen among children, accounting for more than $70 \%$ of pediatric renal masses and usually occurs during the first 2-5 years of life. Out of all Wilms' tumor, the bilateral Wilms' tumor account for around 6$7 \%$. Niu HC et al. reported bilateral lesions in $40 \%$ of Wilms' tumor associated with nephroblastomatosis and also that higher recurrence and metastatic rates are seen in Nephroblastomatosis related Wilms' tumor. ${ }^{5}$ Even though nephrogenic rests are a predisposing condition for the development of Wilms tumor, not all kidneys with nephrogenic rests develop into the same. A significantly higher incidence of bilateral Wilms' tumor and metastasis was found in girls and infants which is also consistent with our case but no evidence of metastasis was seen in our case. ${ }^{6}$

\section{REFERENCES}

1. Lonergan GJ, Martínez-León MI, Agrons GA, Montemarano H, Suarez ES. Nephrogenic rests, nephroblastomatosis, and associated lesions of the kidney. RadioGraphics 1998;18(4):947-68.

2. Beckwith JB, Kiviat NB, Bonadio JF. Nephrogenie rests, nephrobtastomatosis, and the pathogenesis of Wilms' tumor. Pediatr Pathol 1990; 10:1-36.

3. White KS, Kirks DR, Bove KE. Imaging of nephroblastomatosis: an overview. Radiology 1992;182(1):1-5.

4. Rohrschneider WK, Weirich A, Rieden K, Darge $\mathrm{K}$, Tröger J, Graf NUS. US, CT and MR imaging characteristics of nephroblastomatosis. Pediatr Radiol 1998;28(6):435-43.

5. Niu HC, Zhang WP, Sun N et al. Chin Med J (Engl). 2015 Sep 20; 128(18): 2539-41.

6. Cozzi F, Schiavetti A, Cozzi DA et al. Conservative management of hyperplastic and multicentric nephroblastomatosis. J Urol. 2004;172:1066-70.
Source of support: Nil, Conflict of interest: None declared
Cite this article as:

Sharma K, Mangla A. A Rare Case Report of an Infant with Bilateral Nephroblastoma. Int Healthcare Res J 2018;1(12):371-372. doi 10.26440/IHRJ/o1_12/150

\section{AUTHOR AFFILIATIONS}

MD (Pediatrics), Private Practitioner

2. MD (Pedriatics), Private Practitioner

\section{Corresponding Author:}

Dr. Ankit Mangla

Flat No. 12075, $6^{\text {th }}$ Floor

Prestige Bella Vista Apartments

Katupakkam, Chennai

For manuscript enquiry/author contact details, e-mail at: maunscriptenquiry.ihri@gmail.com

\section{LEGENDS}

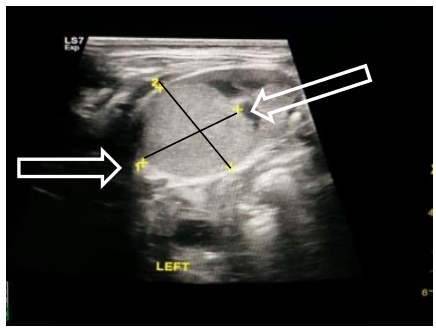

Figure 1. Ultrasound showing Echogenic Mass

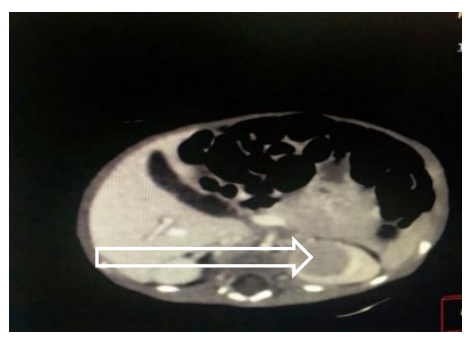

Figure 2. CT Scan Showing Hypodense Space Occupying Lesion 